\title{
PREDICTION OF VOLCANIC ERUPTIONS BY PSEUDO-ANALYTIC FUNCTIONS
}

\author{
T. H. Miyazaki \\ Kokushikan University, Tokyo
}

\begin{abstract}
Imminent Oshima Large Volcanic Eruption in Oshima Island near metropolitan Tokyo, Japan, was successfully predicted by a practical method of modeling and numerical simulation. The event showed the same tendency against Earth Tides with the possible 2023-June-6-Mid-Europe-Gigantic-Earthquake and 2042-August-6-Biscay-Alps-Black-Sea-Trech-Gigantic-Earthquake. Huge and large earthquakes and volcanic eruptions were triggered by their peculiar effective Earth Tides. The event scrutinized here fully acted as plate tectonics and a mathematical model as viscoelastic fluid phenomena.

At the first stage of the simulation, an elastic-viscoplastic porous medium replaced the actual geologic structure, and then conventional theories for random signals and noises determined the most possible vent of eruption. At the next stage, the temporal three-dimensional pseudo-analytic function solver gave the dynamical simulation of the event in Oshima Island. An integrated procedure of direct and indirect solvers minimized variety types of inevitable ambiguities in the modeling and numerical simulation. The event was given in minute-order and in Japan Standard Time.
\end{abstract}

Недавнее большое извержение вулкана Ошима на острове Ошима близ Токио (Япония) было успешно предсказано практическим методом моделирования и численных симуляций. Поведение этого явления то же, что и у предсказуемых землетрясений, которые вероятны 6 июня 2023 г. в среднеевропейской области и 6 августа 2042 г. в области Бискайский залив - Альпы - Черное море - Трех. Эти сильные и обширные землетрясения и извержения вулканов являются следствием особенно действенных для них земных приливов. Событие, подробно здесь исследуемое, полностью описано с учетом тектоники земной поверхности, а с помощью математической модели — как явление вязкоупругой жидкости.

На первой стадии симуляции упругая-вязкоупругая пористая среда заменяет реальную геологическую структуру, а затем с помощью общеизвестных теорий случайных сигналов и шумов определяется наиболее возможный кратер извержения. На следующей стадии с помощью временной трехмерной псевдоаналитической функции получается решение, позволяющее провести динамическую симуляцию события на острове Ошима. Интегрированная процедура прямого и косвенного решателей позволяет минимизировать множество получающихся типов неопределенностей, неизбежно возникающих при моделировании и численной симуляции. Событие описано по минутам и задано по стандартному времени Японии.

PACS: 02.60.-X; 91.40.-K

\section{INTRODUCTION}

The practical method of modeling and numerical simulation [1] was applied for the prediction of large volcanic eruptions. The event was fully dependent on the plate tectonics with effective Earth Tides and mathematically modeled viscoelastic fluid phenomena. Geologic structures were replaced by elastic-viscoplastic porous media, temporal three-dimensional pseudo-analytic function solvers dynamically simulationed the events, and conventional theories for random signals and noises determined the most possible vent of eruption. In order to 
minimize variety types of ambiguities appeared in the modeling and numerical simulation, an integrated procedure of direct and indirect solvers was also introduced.

Oshima Volcano, usually called as Mihara Volcano, was scrutinized as a prior decisive simulation for the possible 2023-June-6-Mid-Europe-Gigantic-Earthquake at 10:30-10:31 with Magnitude of 8.45 to 8.48 and 2042-August-6-Biscay-Alps-Black-Sea-Trech-GiganticEarthquake at 9:51-9:52 with Magnitude of 8.25 to 8.28. After identifying the eruptive vent, the volcano structure was three-dimensionally mapped and assumed as a network of thermal magma flow chambers. The statistical random signal analysis gave directional tendencies of low frequency earthquakes, low magnitude swarms or sequentially occurred earthquake waveforms with long time durations. Also, isotropic components in the moment tensors were detectable in the network area. From the synthesis of directional tendencies in the time series data of all high- and low-frequency earthquakes, the possible eruptive vent was identified. Eventually, the time series data were rearranged along with the assumed magma flow network. Further analysis of depths and magnitudes of high- and low-frequency earthquakes revealed the molded and under-molding magma chambers which directly leaded to the prediction of imminent volcanic eruption.

\section{GOVERNING EQUATION AND BOUNDARY CONDITIONS}

The governing equation for the present prediction and the terms shown with capital letters are almost the same as before [1]. The geometric inclinations of hypothetical thermo-fluid magma flow channel surfaces primary effected to Earthquakes Effectiveness of Earth Tide (E.T.) for the peculiar events. The scenario of main and temporary magma chamber developments for the respective event shall be often forced to be altered by the neighbor volcanic activities. Effectiveness threshold-bands for the precursory events, leading to volcanic eruptions, were characteristics to respective events. We introduced a parametric representation with respect to Strength of E.T., Geometric Conditions, Intrinsic-Magma-Chamber-Condition, and Effect of Neighborhood to Effectiveness Coefficients. Stiffness of Thermo Magnetic Flow System and Equivalent Traction Surface, corresponding to an earthquake fault surface, gave practical robust approximations. Effectiveness Coefficient for peculiar volcanic eruptions was suibjected to their ambient conditions. The stress function was postulated as sectionally continuous. Eventually, the present prediction of volcanic eruption by artificial flexible thermal porous walls with crack distributions ended successfully.

The reduced fundamental equation for $\vartheta_{n}$ was readily accomplished by continuing the realvalued coefficients pseudo-analytically to complex ones [2-7]. At the final stage of tectonic stress buildup by E.T., the subsidiary vents were determined as follows. Refferring to available geological reference data, several $x-r$ computation surfaces and the boundaries of domains corresponding to referred seismic areas for respective events were preliminary arranged. Under quasi-steady state conditions, the hypothetical boundaries of mathematical domains were successively adjusted through numerical computations. Now the pseudo-analytic function solvers [2-7] implanted the given $\vartheta_{n}$ at $z_{n, m}(m=1, \ldots, \psi)$ and quasi-steady state conditions such that:

$$
\frac{\tau\left(z_{n}, \zeta_{n}\right)}{2}\left[\vartheta_{n}\left(z_{n}, \zeta_{n} ; t_{j}, p_{j}, \rho_{j}, T_{j}\right)\right]_{N+1}=\frac{\tau\left(z_{n}, \zeta_{n}\right)}{2}\left[\vartheta_{n, i}\left(z_{n} ; t_{j}, p_{j}, \rho_{j}, T_{j}\right)\right]_{N}+
$$




$$
\begin{gathered}
+\frac{\tau\left(z_{n}, \zeta_{n}\right)}{2}\left[\Psi_{n}\left(z_{n}, \zeta_{n} ; t_{j}, p_{j}, \rho_{j}, T_{j}\right)\right]_{N}- \\
-\frac{1}{2 \pi i} \oint_{G_{n}} \frac{\tau\left(z_{n}^{\prime}, \zeta_{n}^{\prime}\right)\left[\Psi_{n}\left(z_{n}^{\prime}, \zeta_{n}^{\prime} ; t_{j}, p_{j}, \rho_{j}, T_{j}\right)\right]_{N}}{z_{n}^{\prime}-z_{n}}\left[1-R_{n}\left(z_{n}^{\prime}, z_{n, 1}, \ldots, z_{n, \psi}\right)\right] d z_{n}^{\prime}, \\
\frac{\partial p_{n}}{\partial n}=\frac{\partial \rho_{n}}{\partial n}=\frac{\partial T_{n}}{\partial n}=0, \quad \text { along } G_{n},
\end{gathered}
$$

where $\tau$ stands for the curvature of boundary $G_{n}$ at $\left(z_{n}, \zeta_{n}\right)$, and $t_{j}, p_{j}, \rho_{j}$ and $T_{j}$ are time, pressure, density and temperature, respectively. $\Psi_{n}$ is a pseudo-analytic function corresponding one-to-one to $\vartheta_{n}$. Also, $\vartheta_{n, i}$ is a holomorphic function ordinarily used as the first approximation of $\vartheta_{n}$ in an iterative process, and $N+1$ and $N$ are iteration numbers of the whole computation process [3]. Inversely applying the above relation (1) with a large number of given $\vartheta_{n}$, sufficiently smooth $\left[\Psi_{n}\left(z_{n}^{\prime}, \zeta_{n}^{\prime} ; t_{j}, p_{j}, \rho_{j}, T_{j}\right)\right]_{N}$ along the boundary of domain numerical was arranged. Then, the whole functional spaces representing physical domains for the mechanical and thermodynamical response systems were easily arranged [1-7].

\section{PREDICTION OF OSHIMA VOLCANIC ERUPTIONS}

Large volcanic eruptions followed their Inevitable Precursories as earthquakes to arrange adequate magma flow paths to open air. The rough survey of magma flow channels over Oshima Island found the historically unknown submerged volcanic crater near the feet of Mihara Volcano and called the former Oshima Volcano Summit Crater (S.C.) North (called as «Rear Desert») and the latter S.C. South (Mihara Volcano). The present study on both magma channels found complete independency between them, except at the fundamental root portion. The former was for huge and large eruptions and the latter for rather moderate and small ones. Refferring to the past eruption data on S.C. South, Inevitable Precursories as earthquakes had Effective Coefficient threshold-band of E.T., which came from the successive procession of magma flows and formation of Magma Chambers.

From the past observations, the three-dimensional domain for the magma flow channel system emerged and the main event and Inevitable Precursory for the present imminent Oshima Eruption were predicted, as shown in Table 1. Scrutinizing of the primarily obtained numerical data found S.C. North and the predicted Inevitable Precursory, which showed unsufficient pressure rising in the channel. Reexamination of pseudo-steady state condition along the boundary revealed the possible Shikine Volcanic Eruption located in the north of Oshima Island, which was not merely suspected, as shown in Table 2. Through trial and errors Effectiveness Coefficient at the past gigantic volcanic eruption was set as 1.00. The threshold-band for the present event analogically obtained from the past data on S.C. South was 0.269 to 0.501 . The band width appeared somewhat large as low Moment Magnitude earthquakes. The present band was wide and ambiguous, since the scale of the event was relatively small to Oshima Volcanic Eruption. For more serious scales of possible events, their band widths become tighter. With the reexamined boundary conditions huge and large types 
Table 1. Original Prediction for Oshima Volcanic Eruption

\begin{tabular}{|c|c|}
\hline Main event & \\
\hline Type & Plinian eruption with scoria explosion \\
\hline Date & July 8, 2006, 22:23-24 (I) \\
\hline Place & S.C. North \\
\hline Scale & $\begin{array}{l}\text { 3.28 times of the 1777-Eruption at S.C. South } \\
\text { (Cinder cone of } 1777-1778 \text { ) }\end{array}$ \\
\hline Duration & $28 \mathrm{~d}$ from the day of serious eruption occurrence \\
\hline Lava flow & $2 \mathrm{~d}$ of duration from S.C. North \\
\hline Date & August 4-5, 2006 \\
\hline Scale & 3.14 times of the 1778-Eruption (Lava flow of 1778) \\
\hline Due evacuation & 2 years and $24 \mathrm{~d}$ from the main event occurrence \\
\hline V.E. activity & $\begin{array}{l}\text { At ninety one and } 35 \mathrm{~min} \text { later the first shock } \\
\text { the radical eruption activity shall occur }\end{array}$ \\
\hline $\begin{array}{l}\text { Inevitable } \\
\text { precursor }\end{array}$ & Low-frequency earthquake \\
\hline Place & Earthquake underneath S.C. North \\
\hline Date & June $23,2006,2: 09-10$ \\
\hline Depth & $3.4-3.6 \mathrm{~km}$ under the sea level \\
\hline Moment magnitude & $3.42-3.44$ \\
\hline Duration time & 2.4 to $2.6 \mathrm{~s}$ \\
\hline Transient chamber & The top: 3.3 to $3.7 \mathrm{~km}$ and the depth: 4.1 to $4.3 \mathrm{~km}$ \\
\hline Mantle origin chamber & The top: 274.3 to $274.7 \mathrm{~km}$ and the depth: 281.2 to $281.4 \mathrm{~km}$ \\
\hline
\end{tabular}

Table 2. Prediction for Shikine Volcanic Eruption

\begin{tabular}{|l|l|}
\hline Main event & \\
\hline Type & Plinian eruption with scoria explosion \\
Date & November 14, 2006, 11:08-11:09 \\
Place & The center of volcanic trace \\
Duration & 9 d from the day of serious eruption occurrence \\
\hline Lava flow & 7 d of duration from the center \\
Date & November 19-26, 2006 \\
Due evacuation & 4 years from the main event occurrence \\
\hline Inevitable precursor & Low-frequency earthquake \\
\hline Date & October $30,2006,2: 09-10$ \\
Place & Earthquake underneath the center \\
Depth & 2.2 to 2.4 km under the sea level \\
Moment magnitude & $3.22-3.48$ \\
Duration time & 2.2 to $2.4 \mathrm{~s}$ \\
Transient chamber & The top: 2.2 to $3.2 \mathrm{~km}$ and the depth: 4.9 to $5.3 \mathrm{~km}$ \\
Mantle origin chamber & The top: 246.3 to $251.9 \mathrm{~km}$ and the depth: 256.9 to $268.3 \mathrm{~km}$ \\
\hline The last scoria explosion & November 8, B.C. 2839 \\
\hline The next scoria explosion & March $8,2048,10: 30-10: 31$ \\
\hline
\end{tabular}


Table 3. Predicted Large Oshima Volcanic Eruptions

\begin{tabular}{|l|l|}
\hline Date and scale & Date and scale \\
\hline B.C. 238 July 10, 1.00 & B.C. 119 Sept. 10, 0.63 \\
B.C. 34 Aug. 6, 0.71 & B.C. 6 Nov. 10, 0.84 \\
B.C. 2 Sept. 8, 0.67 & 28 Nov. 6, 0.67 \\
123 July 9, 0.78 & 2006, July 31, 21:03-21:04, 0.61 \\
2023 July 7, 22:10-22:11, 0.67 & 2026 Sept. 8, 20:03-20:04, 0.85 \\
2031 Aug. 21, 16:31-16:32, 0.98 & 2036 June 30, 20:01-20:02, 0.67 \\
2039 Sept. 3, 8:01-8:02, 0.92 & 2041 July 6, 23:02-23:03, 0.73 \\
2044 Aug. 21, 2:02-2:03, 0.85 & 2073 Aug. 8, 21:09-21:10, 1.00 \\
\hline
\end{tabular}

Table 4. Expected Event Dates and Precursory Cases

\begin{tabular}{|l|l|}
\hline Expected event dates & Expected event dates \\
\hline July 21,2006 (II) $21: 43$ to $21: 44$ & July 26,2006 (III) $4: 24$ to $4: 25$ \\
\hline July 29,2006 (IV) $4: 11$ to $4: 12$ & July 31,2006 (V) $21: 03$ to $21: 04$ \\
\hline Precursory chances and scales for (IV) & Precursory chances and scales for (V) \\
\hline July $13,2006,4: 09$ to $4: 10.0 .483$ & July $16,2006,21: 38$ to $21: 39.0 .324$ \\
July $13,2006,10: 07$ to $10: 08.0 .436$ & July $17,2006,2: 09$ to $2: 10.0 .338$ \\
July $13,2006,19: 49$ to $19: 50.0 .478$ & July $17,2006,23: 02$ to $21: 03.0 .398$ \\
July $13,2006,21: 09$ to $21: 10.0 .415$ & July $18,2006,3: 08$ to $3: 09.0 .414$ \\
July $13,2006,23: 03$ to $23: 04.0 .464$ & July $18,2006,10: 09$ to $10: 10.0 .422$ \\
July $14,2006,2: 09$ to $2: 10.0 .414$ & July $18,2006,13: 08$ to $13: 09.0 .464$ \\
July $14,2006,4: 27$ to $4: 28.0 .493$ & July $18,2006,18: 21$ to $18: 22.0 .394$ \\
July $14,2006,11: 01$ to $11: 02.0 .464$ & July $18,2006,22: 27$ to $22: 28.0 .414$ \\
July $14,2006,13: 08$ to $13: 09.0 .278$ & July $18,2006,23: 38$ to $23: 39.0 .436$ \\
July $14,2006,16: 24$ to $16: 25.0 .398$ & July $19,2006,2: 01$ to $2: 02.0 .483$ \\
July $14,2006,19: 31$ to $19: 32.0 .444$ & July $19,2006,3: 03$ to $3: 04.0 .464$ \\
July $14,2006,21: 02$ to $21: 03.0 .476$ & July $19,2006,7: 22$ to $7: 23.0 .483$ \\
July $14,2006,23: 38$ to $23: 39.0 .483$ & July $19,2006,9: 09$ to $9: 10.0 .414$ \\
July $15,2006,4: 41$ to $4: 42.0 .394$ & July $19,2006,12: 22$ to $12: 23.0 .364$ \\
July $15,2006,9: 38$ to $9: 39.0 .468$ & July $19,2006,14: 48$ to $14: 49.0 .412$ \\
July $15,2006,18: 42$ to $18: 43.0 .494$ & July $19,2006,18: 33$ to $18: 34.0 .493$ \\
\hline
\end{tabular}

of Oshima Volcanic Eruptions were predicted and shown in Table 3. Applying of renewed conditions, expected event dates and their precursory candidates were shown in Table 4 . The Figure shows five independent detailed candidate dates and Effectiveness Coefficients instead of the single Precursory occurrence condition. Actual Oshima Volcanic Eruption began on July 31, 2006, corresponding to the last case data. The real formation of Summit Crater begun on July 28, just as predicted. The past huge and large Oshima Volcanic Eruptions given were verified through newly found exposed strata in the south-west of Oshima Island. 


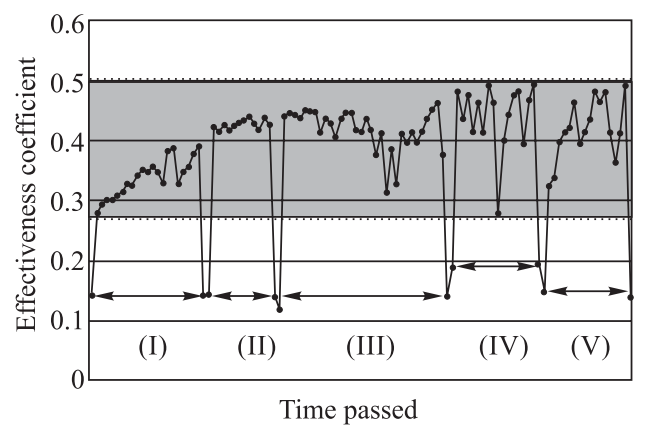

Candidate distributions for Inevitable Precursory for respective Expected Event Dates. Candidates in Block (I) for July 6, 2006; (II) for July 21, 2006; (III) for July 26, 2006; (IV) for July 29, 2006, and (IV) for July 31

\section{CONCLUSIONS}

The present pseudo-analytical function solver successfully predicted large volcanic eruptions with ambiguous circumferential conditions. Hypothetical boundary conditions employed in the numerical simulation sqeezed out unknown submerged volcanic craters and the unexpected volcanic eruption. Parametric of circumferential variables introduced in the present solver discriminated entangled adjacent volcanic magma flow channels. The present numerical results demonstrated a practical scheme for simulations of large-scale physical phenomena on the spot and promised the future simulation for the possible 2023-Mid-Europe- and 2042-August-6-Biscay-Alps-Black-Sea-Trench-Gigantic-Earthquakes.

\section{REFERENCES}

1. Miyazaki T. ICESe02. Paper ID:190. Tech. Sci. Press, 2002. P.1-6.

2. Miyazaki T. // ISUAAAT. 2000. V.13. P.322-331.

3. Miyazaki T. // Computers \& Fluids. 1998. V.27, No.5-6. P.619-637.

4. Miyazaki T. Modeling and Simulation Based Engineering. Tech. Sci. Press, 1998. P.905-910.

5. Miyazaki T. // ICAS-96-1.7. 1996. V.2. P. 1468-1478.

6. Miyazaki T. // ICAS-94-6.5.3. 1994. V.2. P. 1718-1727.

7. Miyazaki T. // C. F. D. J. 1994. V.3. P. 379-394. 